\section{Kidney \\ Blood Pressure Research}

Original Paper
Kidney Blood Press Res 2014;39:230-239

\title{
Sclerostin Blood Levels Before and After Kidney Transplantation
}

\author{
Marco Bonani ${ }^{a} \quad$ Daniel Rodrigueza,b Thomas Fehr ${ }^{\mathrm{a}} \quad$ Nilufar Mohebbia \\ Jens Brockmann ${ }^{c} \quad$ Markus Blum $^{\mathrm{a}} \quad$ Nicole Graf $^{\mathrm{d}}$ Diana Frey ${ }^{\mathrm{e}}$ Rudolf P. Wüthrich ${ }^{\mathrm{a}}$ \\ aDivision of Nephrology, University Hospital Zürich; bInstitute of Physiology, University of Zürich; \\ 'Division of Visceral and Transplantation Surgery, University Hospital Zürich; ' ${ }^{\prime}$ raf biostatistics,

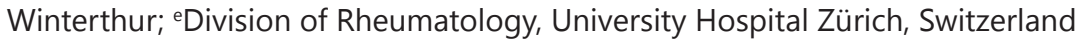

\section{Key Words}

Sclerostin $\cdot$ Kidney transplantation $•$ Bone mineral metabolism

\begin{abstract}
Background/Aims: Sclerostin is secreted by osteocytes. As a circulating inhibitor of the Wnt-signaling pathway it inhibits bone formation and contributes to the development of osteoporosis. Sclerostin levels are elevated in patients with chronic kidney disease and end-stage renal disease. Since data for patients after kidney transplantation are scarce, we have prospectively measured sclerostin levels before and during the first year after renal transplantation and have examined the association of sclerostin with parameters of bone mineral metabolism and with bone mineral density. Methods: Sclerostin levels were measured by ELISA in 42 consecutive renal transplant recipients before and at defined intervals in the first year after transplantation. Bone mineral density was measured by dual energy X-ray absorptiometry. Results: Pre-transplant serum sclerostin levels were elevated in all patients $(61.8 \pm 32.3 \mathrm{pmol} / \mathrm{l}$, normal range $20-30 \mathrm{pmol} / \mathrm{l})$. Within 15 days after transplantation and correlating with the improvement of renal function, sclerostin levels dropped to $21.0 \pm 14.7$ $\mathrm{pmol} / \mathrm{l}$ and subsequently increased to $23.8 \pm 14.9$ and $28.0 \pm 16.8 \mathrm{pmol} / \mathrm{l}$ after 6 and 12 months, respectively $(P<0.001)$. A linear mixed model indicated that pre-transplant sclerostin levels $(P<0.001)$ and time after transplantation $(P<0.001)$ were the most important predictors for the rise of post-transplant sclerostin levels. No correlation was found between posttransplant sclerostin levels and bone mineral density. Conclusions: The rapid reduction of elevated serum sclerostin levels shortly after kidney transplantation parallels the improvement of renal function, but contrasts with the more delayed improvement of hyperparathyroidism. The normalization of both hormones could contribute to improved bone health after renal transplantation.
\end{abstract}




\section{Kidney \\ Blood Pressure Research}

Kidney Blood Press Res 2014;39:230-239

\begin{tabular}{l|l}
\hline DOI: $10.1159 / 000355781$ & (C) 2014 S. Karger AG, Basel
\end{tabular}

Publisnea ontrne: July 3I, 2014

www.karger.com/kbr

231

\section{Introduction}

Changes in bone mineral metabolism occur early in the course of chronic kidney disease (CKD) progression and aggravate with continued loss of kidney function. A number of different bone disease patterns emerge in patients with renal failure which are collectively referred to the acronym Chronic Kidney Disease-Mineral and Bone Disorder (CKD-MBD) [1]. After kidney transplantation some of these bone alterations persist, including lesions associated with hyperparathyroidism, hyperphosphatoninism and vitamin D deficiency. Furthermore, renal allograft recipients are at high risk for bone loss and osteoporosis during the first year after transplantation [2], particularly under the influence of immunosuppressive therapy [3].

The Wnt signaling pathway is involved in the regulation of bone metabolism, especially in bone formation [4]. Sclerostin - a $22 \mathrm{kDa}$ glycoprotein secreted by osteocytes - is a soluble inhibitor of the canonical Wnt pathway. By binding to the LRP5/6 receptors it functions as an inhibitor of bone formation at the level of osteoblasts [5]. Sclerostin is the gene product of SOST which is located on chromosome 17q12-21. Sclerostin knockout mice show increased bone formation, and the human counterparts are rare genetic bone diseases (sclerosteosis and van Buchem disease) which are characterized by generalized hyperostosis in the absence of sclerostin [6-8].

Sclerostin levels are elevated in patients with CKD and ESRD $[9,10]$, paralleling the rise in PTH and FGF-23. Sclerostin might play a significant role in the pathogenesis of renal osteodystrophy, although its precise function in CKD-MBD has not been elucidated yet. A recent study suggested that the survival in dialysis patients is improved if the sclerostin values are high [11]. Since data regarding sclerostin in patients after kidney transplantation are scarce we prospectively studied the changes of sclerostin before and during the first year after renal transplantation, and identified the major factors associating with the change of post-transplant sclerostin levels.

\section{Materials and Methods}

\section{Patients and Study Design}

The Denosumab for Prevention of Osteoporosis in Renal Transplant Recipients (POSTOP) study is an ongoing randomized controlled clinical trial testing the efficacy of Denosumab to prevent the loss of bone mineral density in the first year after renal transplantation (NCT01377467). The present study used serum samples from the first 42 study patients to analyze the course of sclerostin before and after renal transplantation. The serum samples were collected from June 2011 until June 2012. The total population of transplanted patients over this time amounted to 107. The study was performed according to International Conference on Harmonisation (ICH)/WHO Good Clinical Practice (GCP) standards. The local medical ethics committee approved the protocol, and all patients provided written informed consent.

Study patients were male or female adult kidney transplant recipients older than 18 years with a functioning graft within 28 days after transplantation, defined by a serum creatinine level $<200 \mu$ mol/l without the need for dialysis or evidence of rejection. Patients were excluded if they had evidence of severe osteoporosis (T-score below -4 at the hip, femoral neck or any of the vertebrae L1 to L4), or if they had a PTH $>800$ or $<10 \mathrm{ng} / \mathrm{l}$, or a serum calcium $<1.8$ or $>2.7 \mathrm{mmol} / \mathrm{l}$. Patients received standard triple immunosuppression including a calcineurin inhibitor (cyclosporine or tacrolimus), mycophenolate and steroids. Induction treatment was performed with basiliximab or anti-thymocyte globulin.

Serum and urine was collected from all patients at baseline (on average 15 days after transplantation) and 3, 6 and 12 months thereafter. An additional serum sample was obtained within 24 hours before transplantation. Sclerostin and parameters of bone mineral metabolism were determined at each visit. 


\section{Kidney \\ Blood Pressure Research}

Kidney Blood Press Res 2014;39:230-239

\begin{tabular}{l|l}
\hline DOI: 10.1159/000355781 & (c) 2014 S. Karger AG, Basel
\end{tabular}

Publisnea ontrne: July 3I, 2014

www.karger.com/kbr

Kidney Transplantation

Laboratory Measurements

After centrifugation during 10 minutes with 3000 cycles per minute, blood samples were stored at $-80^{\circ} \mathrm{C}$ until the analysis. Serum sclerostin levels were all measured with a highly sensitive $2^{\text {nd }}$ generation ELISA kit (TECOmedical AG, Sissach, Switzerland), according to the instructions provided by the manufacturer [12]. Values were expressed in $\mathrm{ng} / \mathrm{ml}$ and pmol/l (conversion factor: $1 \mathrm{ng} / \mathrm{ml}=43.48 \mathrm{pmol} / \mathrm{l}$ ). The ELISA has a reported intra- and inter-assay coefficient of variation of $3.1 \%$ and $3.5 \%$, respectively.

The parameters of bone mineral metabolism (calcium, phosphate, $\mathrm{PTH}, 25(\mathrm{OH})$ vitamin $\mathrm{D}_{3}, 1,25(\mathrm{OH})_{2}$ vitamin $\mathrm{D}_{3}$ and urine deoxypyridinoline) were measured with standard laboratory techniques. The eGFR was calculated according to the CKD-EPI formula.

\section{Dual Energy X-Ray Absorptiometry (DXA)}

Bone mineral density (BMD) was measured at the lumbar spine and at the left hip by dual energy $\mathrm{X}$-ray absorptiometry (DXA) at baseline (on average 15 days after transplantation) with a Hologic QDR 4500 A device. The results are expressed as absolute values in $\mathrm{g} / \mathrm{cm}^{2}$ hydroxylapatite and also as relative values in number of SD below the expected normal gender- and ethnicity-adjusted BMD value (T-score). The total lumbar spine BMD was calculated by averaging the BMD of vertebrae L1 to L4. At the hip the values of the total hip BMD were used.

\section{Statistical Analyses}

All analyses were performed using SPSS Version 20. Figures were done in R [13]. Data for parameters of bone mineral metabolism are reported as mean $\pm \mathrm{SD}$, or percentage where appropriate. Differences between the visits (pre-transplant, post-transplant, and after 12 months) were tested with pairwise comparisons (unadjusted P-values) in the context of a General Linear Model (GLM) for repeated measures. Differences in pre-transplant sclerostin values between groups were tested with an independent samples $t$-test. The Pearson correlation coefficient was computed to account for the correlation between age and sclerostin.

Using a linear mixed model we analyzed whether there was a time-dependent increase in sclerostin after transplantation, and which variables would possibly account for this increase. The maximum likelihood (ML) method was used to estimate the parameter values of the linear mixed model. Normality was checked with a Q-Q plot for the residuals, and homoscedasticity was evaluated with a residuals versus predicted values plot. Sclerostin had to be log-transformed to achieve the assumption of normality. In a first step, a random effects model was implemented to evaluate whether sclerostin values differed between the posttransplantation visits. Subsequently, potential predictors were tested and included in a linear mixed model if $\mathrm{P}<0.20$. Factors tested included parameters for CKD-MBD (calcium, phosphate, magnesium, $\mathrm{PTH}, 25(\mathrm{OH})$ vitamin $\mathrm{D}_{3}, 1,25(\mathrm{OH})_{2}$ vitamin $\mathrm{D}_{3}$, sclerostin pre-transplantation, urine deoxypyridinoline/creatinine ratio, urine calcium/creatinine ratio, urine phosphate/creatinine ratio, bone mineral density (BMD) at the lumbar spine and at the left hip (g/ $\mathrm{cm}^{2}$ and T-score by DXA)), drug treatments (ever receiving calcium, vitamin $\mathrm{D}$, denosumab, cinacalcet, bisphosphonates, tacrolimus or cyclosporine in the post-transplant period) and others (age, gender, time after transplantation, BMI, creatinine and eGFR, urine protein/creatinine ratio, CRP, glucose, hemoglobin and MCV). Different nested models were then compared with the likelihood ratio test and Akaike's Information Criterion (AIC). The final model included a random intercept and pretransplant sclerostin and time after transplantation as fixed effects.

\section{Results}

\section{Patient population}

Demographic and baseline characteristics of the study population are presented in Table 1 . The mean age of the recipients was $49 \pm 14$ years and $64 \%$ were males. The majority were Caucasian (88\%) and transplanted for the first time (88\%). Most patients were hypertensive (90\%) and 14\% were diabetic. A majority of the patients (88\%) were on dialysis, $12 \%$ underwent preemptive transplantation. Induction therapy consisted of basiliximab (72\%) or anti-thymocyte globulin (26\%) according to the immunological risk. 


\section{Kidney \\ Blood Pressure Research}

Kidney Blood Press Res 2014;39:230-239

\begin{tabular}{l|l}
\hline DOI: $10.1159 / 000355781$ & (C) 2014 S. Karger AG, Basel
\end{tabular}

Publisnea onine: Jury 31, 2014

www.karger.com/kbr

Bonani/Rodriguez/Fehr/Mohebbi/Brockmann/Blum/Graf/Frey/Wüthrich: Sclerostin after Kidney Transplantation
Table 1. Demographic and baseline characteristics of transplanted patients

\begin{tabular}{|c|c|}
\hline $\mathrm{N}$ & 42 \\
\hline Age (years) & $49 \pm 14$ \\
\hline Men & $27(64)$ \\
\hline Caucasian & $37(88)$ \\
\hline Body mass index $\left(\mathrm{kg} / \mathrm{m}^{2}\right)$ & $25.8 \pm 5.8$ \\
\hline Patients with a first transplant & $37(88)$ \\
\hline Living donor transplantation & $20(48)$ \\
\hline \multicolumn{2}{|l|}{ Renal disease leading to ESRD: } \\
\hline Polycystic kidney disease & $12(29)$ \\
\hline Chronic glomerulonephritis & $11(26)$ \\
\hline Hypertensive nephropathy & $5(12)$ \\
\hline Diabetic nephropathy & $4(9)$ \\
\hline Other & $10(24)$ \\
\hline \multicolumn{2}{|l|}{ Pre-transplant dialysis mode: } \\
\hline Hemodialysis & $31(74)$ \\
\hline Peritoneal dialysis & $6(14)$ \\
\hline Preemptive transplantation & $5(12)$ \\
\hline \multicolumn{2}{|l|}{ Immunosuppression: } \\
\hline Basiliximab induction & $30(72)$ \\
\hline Thymoglobulin induction & $11(26)$ \\
\hline Tacrolimus & $22(52)$ \\
\hline Cyclosporine & $20(48)$ \\
\hline Mycophenolate & $42(100)$ \\
\hline Prednisone & $42(100)$ \\
\hline \multicolumn{2}{|l|}{ Post-transplant treatment for CKD-MBD: } \\
\hline Vitamin D & $32(76)$ \\
\hline Calcium & $27(64)$ \\
\hline Denosumab & $21(50)$ \\
\hline Cinacalcet & $2(5)$ \\
\hline Bisphosphonate & $0(0)$ \\
\hline \multicolumn{2}{|l|}{ Bone mineral density (DXA): } \\
\hline Total hip $\left(\mathrm{g} / \mathrm{cm}^{2}\right)$ & $0.897 \pm 0.116$ \\
\hline Total hip (T-score) & $-0.700 \pm 0.854$ \\
\hline Total lumbar spine $\left(\mathrm{g} / \mathrm{cm}^{2}\right)$ & $0.975 \pm 0.128$ \\
\hline Total lumbar spine (T-score) & $-0.959 \pm 1.144$ \\
\hline
\end{tabular}

Maintenance immunosuppression consisted of a calcineurin inhibitor (tacrolimus $52 \%$ or cyclosporine $48 \%$ ), combined with mycophenolate and prednisone. Prednisone was tapered over six months to $5 \mathrm{mg}$ per day and was then gradually withdrawn in twothirds of the patients until one year after transplantation. All patients were prescribed standard treatment for post-transplant CKD-MBD, which included calcium (1000 mg/d) and vitamin D $(800 \mathrm{IU} / \mathrm{d})$. Half of the patients were treated with denosumab (60 mg s.c. every 6 months) as part of the POSTOP study protocol. During the course of the study two patients received cinacalcet, and one was treated with bisphosphonates. At the hip $16(38 \%)$ of the patients were osteopenic (T-score between -1.0 and -2.5) and none was osteoporotic (T-score below -2.5); at the lumbar spine $14(33 \%)$ were osteopenic, and $5(12 \%)$ were osteoporotic.

Pre- and post-transplant changes of sclerostin and parameters of bone mineral metabolism

As expected, the pretransplant serum sclerostin levels were elevated, amounting to $61.8 \pm 32.3 \mathrm{pmol} / \mathrm{l}$ (normal range 20-30 pmol/l). The underlying kidney disease did not influence pre-transplant sclerostin levels, and there was no significant difference between males and females (66.7 \pm 28.7 vs. $58.7 \pm 40.9 \mathrm{pmol} / \mathrm{l}, \mathrm{P}=0.46$ ) (Figure $1 \mathrm{~A}$ ), but there was a positive correlation with age $(\mathrm{r}=0.404, \mathrm{P}=0.008)$. Pre-transplant sclerostin levels did not correlate with BMD. Interestingly pre-transplant sclerostin levels were lower in patients treated with peritoneal dialysis compared with those on hemodialysis (39.2 \pm 15.8 vs. $70.1 \pm 33.9$ pmol/l, $\mathrm{P}=0.038$ ) (Figure 1B).

Within 15 days after transplantation and correlating with the improvement of renal function, serum sclerostin levels dropped to $21.0 \pm 14.7 \mathrm{pmol} / \mathrm{l}$ and increased significantly to $23.8 \pm 14.9$ and $28.0 \pm 16.8 \mathrm{pmol} / \mathrm{l}$ after 6 and 12 months, respectively $(\mathrm{P}<0.001)$. Figure 2 displays the pre- and post-transplant sclerostin values of the 42 patients, illustrating the marked drop of sclerostin shortly after transplantation and the subsequent gradual rise of sclerostin. The median increase of sclerostin amounted to 49.4\% (IQR 10.7 - 98.1\%). Figure 2 also reveals that higher pre-transplant sclerostin levels resulted in higher levels after transplantation. 


\section{Kidney \\ Blood Pressure Research}

Kidney Blood Press Res 2014;39:230-239

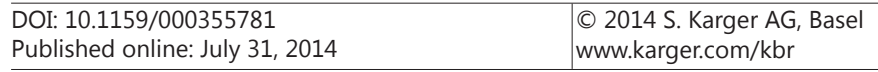

234 Kidney Transplantation

Shortly after transplantation the mineral metabolism parameters showed persisting hyperparathyroidism, low $25(\mathrm{OH})$ vitamin $\mathrm{D}_{3}$ levels and hypophosphatemia, as expected for this patient population (Table 2). PTH continuously decreased whereas phosphate levels gradually rose during the first year after transplantation. Calcium, $25(\mathrm{OH})$ vitamin $\mathrm{D}_{3}$ and $1,25(\mathrm{OH})_{2}$ vitamin $\mathrm{D}_{3}$ levels also rose during the first year after transplantation, presumably due to the treatment with calcium and vitamin D.

Factors associated with sclerostin levels after transplantation

Using a mixed linear model we analyzed which variables would account for the timedependent increase in posttransplant sclerostin. We first analyzed all relevant variables for their individual fixed effect, and then developed a model which would predict multiple fixed effects.

The linear mixed model analysis revealed that the following variables had a significant positive fixed effect on post-transplant sclerostin levels: age $(\mathrm{P}=0.034)$, time after transplantation $(\mathrm{P}<0.001)$, serum phosphate $(\mathrm{P}=0.009)$, serum magnesium $(\mathrm{P}=0.024)$, $25(\mathrm{OH})$ vitamin $\mathrm{D}_{3}(\mathrm{P}=0.048)$, pre-transplantat sclerostin $(\mathrm{P}<0.001)$, hemoglobin $(\mathrm{P}=0.002)$ and treatment with

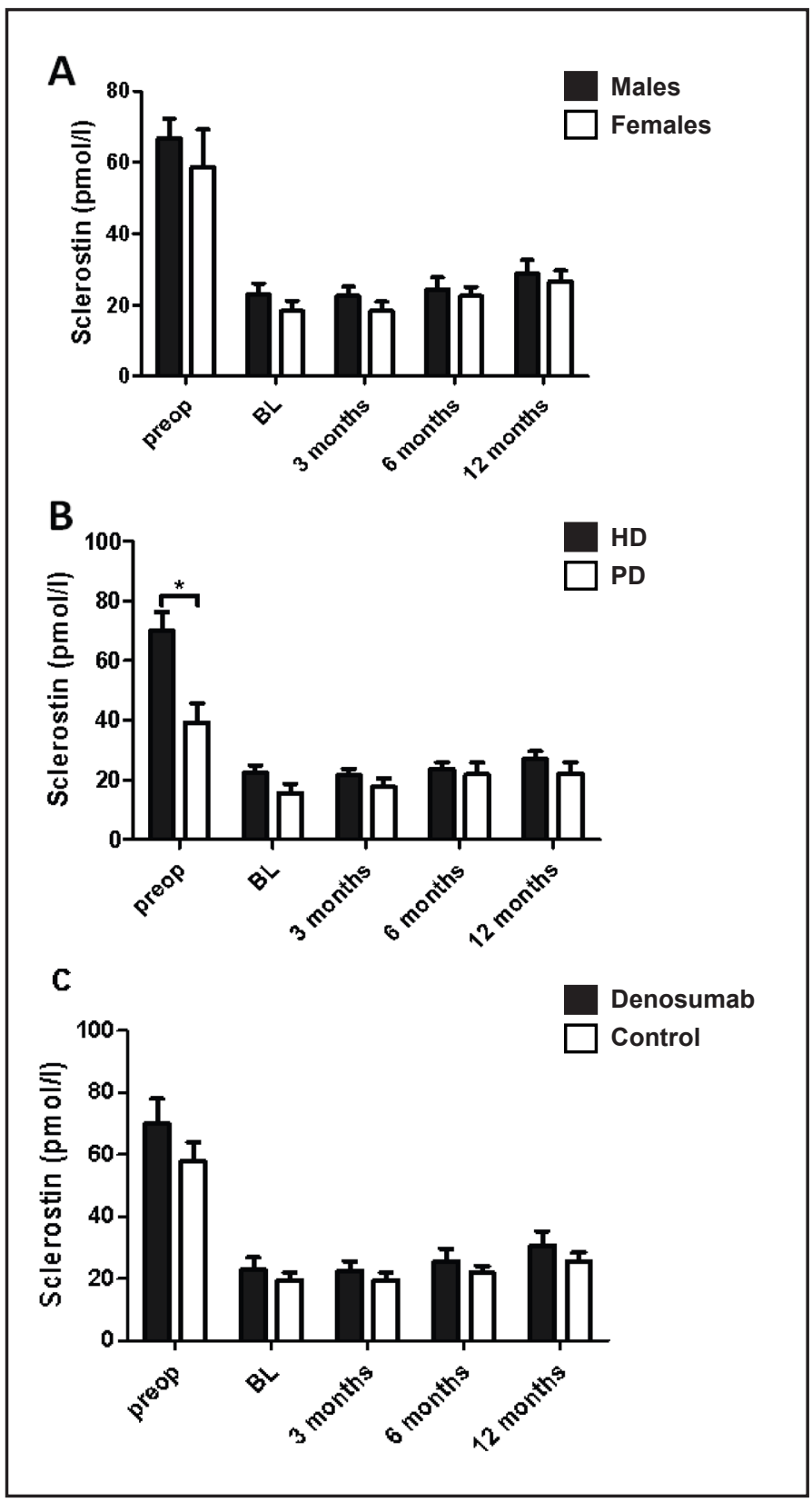

Fig. 1. Serum sclerostin levels (pmol/l) over time in A) males vs. females, B) hemodialysis (HD) vs. peritoneal (PD) patients $(* \mathrm{p}=0.038), \mathrm{C})$ denosumab-treated vs. control patients. Data are reported as mean $\pm \mathrm{SD}$. vitamin $\mathrm{D} \quad(\mathrm{P}=0.023)$. Blood calcium $(\mathrm{P}=0.057)$, urine creatinine $(\mathrm{P}=0.093)$, and deoxypyridinoline/creatinine ratio $(\mathrm{P}=0.165)$ had $\mathrm{p}$-values $<0.20$. $\mathrm{PTH}(\mathrm{P}=0.003)$, glucose $(\mathrm{P}=0.046)$, $\mathrm{MCV}(\mathrm{P}=0.003)$, urine protein/creatinine ratio $(\mathrm{p}=0.010)$, and $\mathrm{BMI}(\mathrm{P}=0.048)$ had a significant negative fixed effect. The eGFR and the baseline BMD at the spine and hip did not have a significant fixed effect on sclerostin. Furthermore, the immunosuppressive drugs tacrolimus and cyclosporine, as well as drugs specific for bone mineral metabolism (calcium, denosumab [Fig. 1C], cinacalcet, bisphosphonates) did not significantly associate with the post-transplant sclerostin levels. 


\section{Kidney Blood Pressure Research}

In the final linear mixed model which is displayed in Table 3 we identified two independent variables which had a significant fixed effect on post-transplant sclerostin levels, namely 1) pretransplant sclerostin levels $(\mathrm{P}<0.001)$, and 2$)$ time after transplantation $(\mathrm{P}<0.001)$. The statistical model includes a random intercept, reflecting the fact that the starting point of the post-transplant sclerostin values differed markedly between the patients. Thus, higher sclerostin levels pretransplant and a longer interval from the time of transplantation predicted higher post-transplant sclerostin levels.

\section{Kidney Blood Press Res 2014;39:230-239}

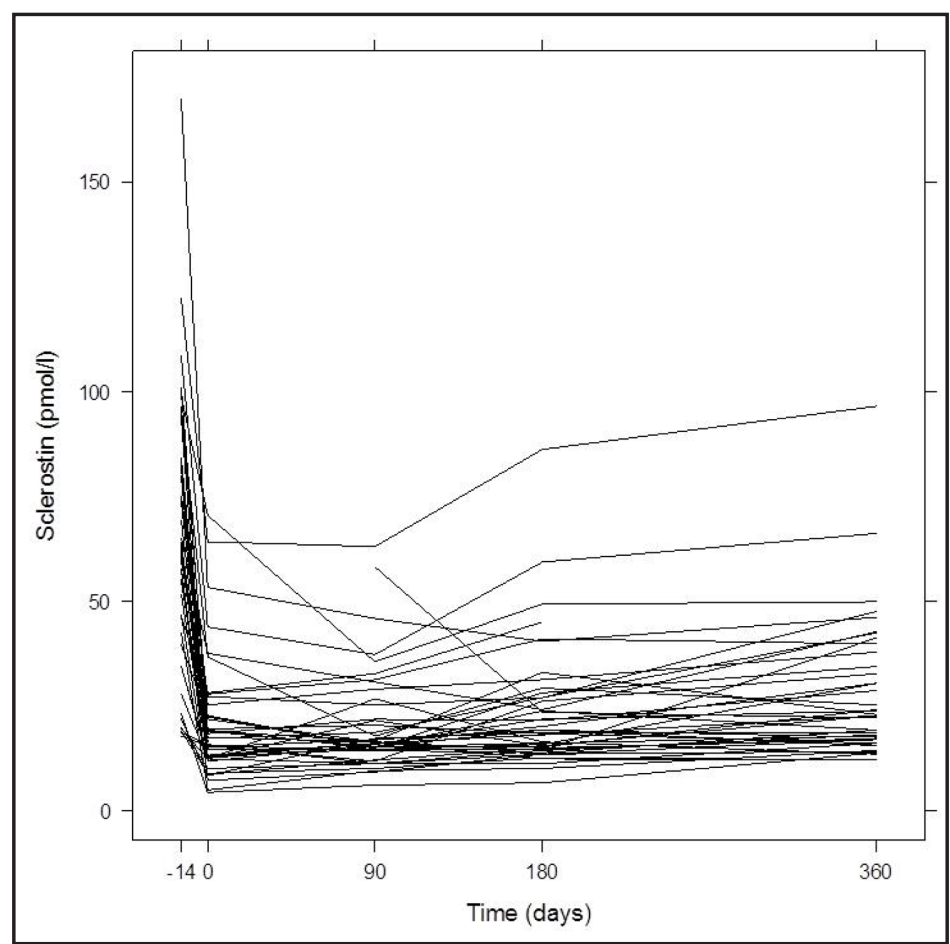

Fig. 2. Course of serum sclerostin measured just before transplantation, at baseline (15 days after transplantation), and 90, 180 and 360 days after baseline.

Table 2. Parameters of CKD-MBD in study patients

\begin{tabular}{|c|c|c|c|c|c|}
\hline Parameter & Pre-transplant & Post-transplant & 3 month & 6 month & 12 month \\
\hline Sclerostin (pmol/l) & $61.8 \pm 32.3$ & $21.0 \pm 14.7^{* * *}$ & $21.0 \pm 12.5$ & $23.8 \pm 14.9$ & $28.0 \pm 16.8^{++\dagger}$ \\
\hline Calcium (mmol/l) & $2.32 \pm 0.18$ & $2.29 \pm 0.19$ & $2.46 \pm 0.17$ & $2.48 \pm 0.17$ & $2.54 \pm 0.15^{+\dagger \dagger}$ \\
\hline Phosphate $(\mathrm{mmol} / \mathrm{l})$ & $1.49 \pm 0.44$ & $0.61 \pm 0.36^{* * *}$ & $0.76 \pm 0.18$ & $0.86 \pm 0.23$ & $0.87 \pm 0.25^{+\dagger \dagger}$ \\
\hline PTH (ng/l) & $340.2 \pm 290.3$ & $180.4 \pm 182.1^{* *}$ & $115.1 \pm 114.2$ & $102.7 \pm 74.74$ & $107.5 \pm 81.1^{\dagger \dagger}$ \\
\hline $25(\mathrm{OH})$ vitamin $\mathrm{D}_{3}(\mu \mathrm{g} / \mathrm{l})$ & - & $17.1 \pm 9.7$ & $22.9 \pm 7.6$ & $22.2 \pm 8.2$ & $26.0 \pm 8.2^{+\dagger \dagger}$ \\
\hline $1,25(\mathrm{OH})_{2}$ vitamin $\mathrm{D}_{3}(\mathrm{ng} / \mathrm{l})$ & - & $28.7 \pm 19.9$ & $53.9 \pm 22.4$ & $55.4 \pm 20.2$ & $53.2 \pm 22.6^{++\dagger}$ \\
\hline $\begin{array}{l}\text { Urine deoxypyridinoline/ } \\
\text { creatinine (nmol/mmol) }\end{array}$ & - & $8.3 \pm 3.2$ & $5.7 \pm 2.7$ & $6.6 \pm 2.9$ & $7.7 \pm 3.3^{\dagger}$ \\
\hline Creatinine $(\mu \mathrm{mol} / \mathrm{l})$ & $623 \pm 217$ & $132 \pm 40.5^{* * *}$ & $128 \pm 37.0$ & $122 \pm 36.3$ & $120 \pm 31.4$ \\
\hline $\mathrm{eGFR}\left(\mathrm{ml} / \mathrm{min} / 1.73 \mathrm{~m}^{2}\right)$ & - & $53.0 \pm 17.4$ & $60.0 \pm 29.6$ & $59.6 \pm 23.2$ & $58.9 \pm 16.9$ \\
\hline
\end{tabular}

\section{Discussion}

The prevention of long-term complications such as osteoporosis and fractures has become very important to ensure optimal outcome after renal transplantation $[2,14]$.
Table 3. Analysis of post-transplant sclerostin levels using a linear mixed model with a random intercept and pre-transplant sclerostin and time as fixed effects

\begin{tabular}{lccc}
\hline Parameter & Estimate & $95 \% \mathrm{CI}$ & P-value \\
\hline Pre-transplant sclerostin & $4.3 \cdot 10^{-3}$ & $2.7 \cdot 10^{-3}-5.8 \cdot 10^{-3}$ & $<0.001$ \\
Time & $4.3 \cdot 10^{-4}$ & $3.1 \cdot 10^{-4}-5.6 \cdot 10^{-4}$ & $<0.001$ \\
Intercept & 0.972 & $0.865-1.080$ & $<0.001$ \\
\hline
\end{tabular}

Bone loss after transplantation is highest in the first 6 to 12 months after transplantation, ranging from $4 \%$ to $9 \%$ at the lumbar spine and from $5 \%$ to $8 \%$ at the hip [2]. Corticosteroids and persistent elevations of PTH and FGF-23 are among the most important factors which determine the early loss of bone mineral density. Recently, sclerostin has been identified as a circulating hormone which - by inhibiting osteoblast formation - promotes osteoporosis 


\section{Kidney Blood Pressure Research}

\begin{tabular}{l|l}
\hline Kidney Blood Press Res 2014;39:230-239 \\
\hline DOI: $10.1159 / 000355781$ & (c) 2014 S. Karger AG, Basel
\end{tabular}

Publisned ontrne: July 31, 2014

www.karger.com/kbr

Bonani/Rodriguez/Fehr/Mohebbi/Brockmann/Blum/Graf/Frey/Wüthrich: Sclerostin after Kidney Transplantation

[7]. We were therefore interested to examine sclerostin levels before and within the first year after transplantation to identify a possible relationship between sclerostin and posttransplant CKD-MBD.

In our study we found a 2-3 fold elevation of sclerostin in ESRD patients before transplantation. This is consistent with other reports which also described elevated sclerostin levels in patients with CKD or ESRD $[9,10,15]$. Shortly after transplantation, sclerostin levels dropped to levels at the lower end of the normal range or in some patients to subnormal values. Subsequently, there was a gradual rise in sclerostin towards normal values within the first year after transplantation. This rise was not influenced by the eGFR, but paralleled the reduction of PTH and the normalization of calcium, phosphate and vitamin D.

How could the marked reduction of sclerostin shortly after transplantation be explained? First of all, the drop in sclerostin levels might be the consequence of improved renal function, i.e. the better clearance of the $22 \mathrm{kDa}$ sclerostin molecule. Little is known regarding the renal clearance of sclerostin. In a recent study it was found quite surprisingly that the renal excretion of sclerostin increased with declining renal function, and it was concluded that the increased serum sclerostin levels in CKD patients were not due to decreased renal elimination [16]. More studies are certainly required to obtain a better understanding of the clearance and metabolism of sclerostin [17]. Secondly, mechanical stress on the skeleton is known to decrease the production of sclerostin by osteocytes [18]. This could contribute to higher sclerostin levels in patients on dialysis who often have a reduced physical activity. Given the fact that patients are physically more active after renal transplantation this could translate to lower sclerostin levels after transplantation. Thirdly, it is likely that the marked change in the drug treatment and in particular the use of glucocorticoids could contribute to the rapid decrease of sclerostin after transplantation. In a study with 17 patients suffering from various medical pathologies requiring systemic steroid therapy, acute treatment with glucocorticoids was found to decrease sclerostin levels, an effect that is probably linked to glucocorticoidinduced apoptosis of osteocytes [19]. Contrary, Gifre et al. showed an increase in sclerostin values in patients treated one year with glucocorticoids [20]. Yet another study described that sclerostin levels were decreased in patients with endogenous hypercortisolism, and increased after correction [21]. In contrast, Belaya et al. reported recently high sclerostin values in patients with Cushing's syndrome [22]. Although it is tempting to speculate that the high steroid dosage immediately after transplantation might have contributed to the rapid decrease of the sclerostin levels, this requires further studies.

Focusing on the individual factors which had an influence on post-transplant sclerostin levels we found that age, time after transplantation, phosphate, magnesium, pre-transplant sclerostin and treatment with vitamin D showed a positive association, whereas BMI and PTH showed a negative association. The association with age is consistent with findings in other patient cohorts $[10,23,24]$. The negative association with PTH is also plausible, since PTH has been shown to directly downregulate sclerostin production in mice [25] and healthy men [26]. We could not find an association between pre- or post-transplant sclerostin and BMD. Such an association has been described in postmenopausal women [27], and in hemodialysis patients [9]. This discrepancy is most likely explained by different demographic and biological factors in patients after renal transplantation, such as younger age and preserved bone mass.

An important finding of our study was that sclerostin levels did not differ between patients treated with denosumab and patients without this treatment (Fig 1C). In contrast to our finding, Gatti et al. found a significant increase in sclerostin levels in postmenopausal women treated with denosumab for osteoporosis compared with the placebo group [28]. The reasons for this discrepancy need to be elucidated. We speculate however that it is due to major differences in these two patient populations, including the immunosuppressive treatment and the pre-existing metabolic bone disease in our patient population. 


\section{Kidney \\ Blood Pressure Research}

Kidney Blood Press Res 2014;39:230-239

\begin{tabular}{l|l}
\hline DOI: 10.1159/000355781 & (C) 2014 S. Karger AG, Basel
\end{tabular}

Publisned onine: July 31, 2014

www.karger.com/kbr

Bonani/Rodriguez/Fehr/Mohebbi/Brockmann/Blum/Graf/Frey/Wüthrich: Sclerostin after Kidney Transplantation

Extending the linear mixed model to more than one fixed effect we found that the best model incorporates only two fixed effects, namely pre-transplant sclerostin and time after transplantation. Thus it appears that the time-dependent regulation of sclerostin production by osteocytes is mainly driven by the sclerostin level before transplantation.

The inhibition of sclerostin might be a promising therapeutic strategy for the preservation of bone mass. Antibodies targeting sclerostin are being developed for the treatment of post-menopausal osteoporosis, showing increased bone growth in preclinical studies in osteoporotic rats and monkeys [29, 30]. In a Phase I study in 72 patients, a single dose of anti-sclerostin antibody (AMG 785, romosozumab) increased bone density in the hip and spine in healthy men and postmenopausal women [31]. Multiple doses of the sclerostin antibody romosozumab in healthy men and postmenopausal women lead to an increase of bone mineral density of 4-7\% at the lumbar spine [32]. In a recently published phase 2 study, postmenopausal women treated with the sclerostin antibody romosozumab also showed an increase in bone mineral density and bone formation after 12 months [33]. Blosozumab, another monoclonal antibody against sclerostin, showed similarly a positive effect on bone mineral density at the lumbar spine after single or multiple dosages [34]. Whether antisclerostin antibody treatment is efficacious to prevent bone loss after renal transplantation would need to be investigated. Since sclerostin levels are already at the lower end of the normal range such a treatment might be less efficacious in newly transplanted patients, also because hyperparathyroid disease and the effects of glucocorticoids predominate.

\section{Conclusions}

We have shown that the markedly elevated sclerostin levels in ESRD patients rapidly drop to normal or subnormal values after renal transplantation, presumably due to the improvement of renal function, increased physical activity and use of glucocorticoids. Subsequently, sclerostin levels increased in the first 12 months after transplantation, in parallel with the decrease of PTH and the normalization of calcium, phosphate and vitamin D metabolites. Our study provides a basis for the further investigation of the role played by sclerostin in bone health after renal transplantation.

\section{Disclosure Statement}

This work is supported by an unrestricted research grant by Novartis (Switzerland). Nicole Graf is the founder and owner of graf biostatistics.

\section{Acknowledgements}

This study was supported by a Matching Fund by the Clinical Trial Center of the University Hospital Zürich. We thank our study coordinator Marian Struker for her help.

\section{References}

1 Moe S, Drueke T, Cunningham J, Goodman W, Martin K, Olgaard K, Ott S, Sprague S, Lameire N, Eknoyan G: Definition, evaluation, and classification of renal osteodystrophy: a position statement from Kidney Disease: Improving Global Outcomes (KDIGO). Kidney Int 2006;69:1945-1953.

$\longrightarrow 2$ Ebeling PR: Approach to the patient with transplantation-related bone loss. J Clin Endocrinol Metab 2009;94:1483-1490. 


\section{Kidney \\ Blood Pressure Research}

Kidney Blood Press Res 2014;39:230-239

\begin{tabular}{l|l}
\hline DOI: 10.1159/000355781 & (c) 2014 S. Karger AG, Basel
\end{tabular}

Publisnea oninne: July 31, 2014

www.karger.com/kbr

Bonani/Rodriguez/Fehr/Mohebbi/Brockmann/Blum/Graf/Frey/Wüthrich: Sclerostin after Kidney Transplantation

-3 Evenepoel P: Recovery versus persistence of disordered mineral metabolism in kidney transplant recipients. Semin Nephrol 2013;33:191-203.

4 Baron R, Rawadi G: Targeting the Wnt/beta-catenin pathway to regulate bone formation in the adult skeleton. Endocrinology 2007;148:2635-2643.

5 Williams BO: Insights into the mechanisms of sclerostin action in regulating bone mass accrual. J Bone Miner Res 2014;29:24-28.

-6 Li X, Ominsky MS, Niu QT, Sun N, Daugherty B, D'Agostin D, Kurahara C, Gao Y, Cao J, Gong J, Asuncion F, Barrero M, Warmington K, Dwyer D, Stolina M, Morony S, Sarosi I, Kostenuik PJ, Lacey DL, Simonet WS, Ke HZ, Paszty C: Targeted deletion of the sclerostin gene in mice results in increased bone formation and bone strength. J Bone Miner Res 2008;23:860-869.

7 Moester MJ, Papapoulos SE, Lowik CW, van Bezooijen RL: Sclerostin: current knowledge and future perspectives. Calcif Tissue Int 2010;87:99-107.

$>8$ van Lierop AH, Hamdy NA, van Egmond ME, Bakker E, Dikkers FG, Papapoulos SE: Van Buchem disease: clinical, biochemical, and densitometric features of patients and disease carriers. J Bone Miner Res 2013;28:848-854.

-9 Cejka D, Jager-Lansky A, Kieweg H, Weber M, Bieglmayer C, Haider DG, Diarra D, Patsch JM, Kainberger F, Bohle B, Haas M: Sclerostin serum levels correlate positively with bone mineral density and microarchitecture in haemodialysis patients. Nephrol Dial Transplant 2012;27:226-230.

10 Pelletier S, Dubourg L, Carlier MC, Hadj-Aissa A, Fouque D: The Relation between Renal Function and Serum Sclerostin in Adult Patients with CKD. Clin J Am Soc Nephrol 2013;8:819-823.

11 Viaene L, Behets GJ, Claes K, Meijers B, Blocki F, Brandenburg V, Evenepoel P, D'Haese PC: Sclerostin: another bone-related protein related to all-cause mortality in haemodialysis? Nephrol Dial Transplant 2013;28:3024-3030.

-12 McNulty M, Singh RJ, Li X, Bergstralh EJ, Kumar R: Determination of serum and plasma sclerostin concentrations by enzyme-linked immunoassays. J Clin Endocrinol Metab 2011;96:1159-1162.

13 Sarkar D: Lattice - Multivariate Data Visualization with R. (ISBN 978-0-387-75968-5) New York, Springer, 2008.

14 Kidney Disease: Improving Global Outcomes (KDIGO) CKD-MBD Work Group: KDIGO clinical practice guideline for the diagnosis, evaluation, prevention, and treatment of Chronic Kidney Disease-Mineral and Bone Disorder (CKD-MBD). Kidney Int Suppl 2009. DOI 10.1038/ki.2009.188.

15 Cejka D, Herberth J, Branscum AJ, Fardo DW, Monier-Faugere MC, Diarra D, Haas M, Malluche HH: Sclerostin and Dickkopf-1 in renal osteodystrophy. Clin J Am Soc Nephrol 2011;6:877-882.

16 Cejka D, Marculescu R, Kozakowski N, Plischke M, Reiter T, Gessl A, Haas M: Renal elimination of sclerostin increases with declining kidney function. J Clin Endocrinol Metab 2014;99:2482-55.

17 Jean G, Chazot C: Sclerostin in CKD-MBD: one more paradoxical bone protein? Nephrol Dial Transplant 2013;28:2932-2935.

18 Robling AG, Niziolek PJ, Baldridge LA, Condon KW, Allen MR, Alam I, Mantila SM, Gluhak-Heinrich J, Bellido TM, Harris SE, Turner CH: Mechanical stimulation of bone in vivo reduces osteocyte expression of Sost/ sclerostin. J Biol Chem 2008;283:5866-5875.

19 Brabnikova Maresova K, Pavelka K, Stepan JJ: Acute effects of glucocorticoids on serum markers of osteoclasts, osteoblasts, and osteocytes. Calcif Tissue Int 2013;92:354-361.

20 Gifre L, Ruiz-Gaspa S, Monegal A, Nomdedeu B, Filella X, Guanabens N, Peris P: Effect of glucocorticoid treatment on Wnt signalling antagonists (sclerostin and Dkk-1) and their relationship with bone turnover. Bone 2013;57:272-276.

-21 van Lierop AH, van der Eerden AW, Hamdy NA, Hermus AR, den Heijer M, Papapoulos SE: Circulating sclerostin levels are decreased in patients with endogenous hypercortisolism and increase after treatment. J Clin Endocrinol Metab 2012;97:2012-2218.

-22 Belaya ZE, Rozhinskaya LY, Melnichenko GA, Solodovnikov AG, Dragunova NV, Iljin AV, Dzeranova LK, Dedov, II: Serum extracellular secreted antagonists of the canonical Wnt/beta-catenin signaling pathway in patients with Cushing's syndrome. Osteoporos Int 2013;24:2191-2199.

23 Modder UI, Hoey KA, Amin S, McCready LK, Achenbach SJ, Riggs BL, Melton LJ, 3rd, Khosla S: Relation of age, gender, and bone mass to circulating sclerostin levels in women and men. J Bone Miner Res 2011;26:373-379. 


\section{Kidney \\ Blood Pressure Research}

Kidney Blood Press Res 2014;39:230-239

DOI: 10.1159/000355781

Published ontIne: July 3I, 2014

(C) 2014 S. Karger AG, Base

www.karger.com/kbr Kidney Transplantation

24 Amrein K, Amrein S, Drexler C, Dimai HP, Dobnig H, Pfeifer K, Tomaschitz A, Pieber TR, Fahrleitner-Pammer A: Sclerostin and its association with physical activity, age, gender, body composition, and bone mineral content in healthy adults. J Clin Endocrinol Metab 2012;97:148-154.

-25 Bellido T, Ali AA, Gubrij I, Plotkin LI, Fu Q, O'Brien CA, Manolagas SC, Jilka RL: Chronic elevation of parathyroid hormone in mice reduces expression of sclerostin by osteocytes: a novel mechanism for hormonal control of osteoblastogenesis. Endocrinology 2005;146:4577-4583.

-26 Yu EW, Kumbhani R, Siwila-Sackman E, Leder BZ: Acute decline in serum sclerostin in response to PTH infusion in healthy men. J Clin Endocrinol Metab 2011;96:2011-1534.

-27 Garnero P, Sornay-Rendu E, Munoz F, Borel 0, Chapurlat RD: Association of serum sclerostin with bone mineral density, bone turnover, steroid and parathyroid hormones, and fracture risk in postmenopausal women: the OFELY study. Osteoporos Int 2013;24:489-494.

28 Gatti D, Viapiana O, Fracassi E, Idolazzi L, Dartizio C, Povino MR, Adami S, Rossini M: Sclerostin and DKK1 in postmenopausal osteoporosis treated with denosumab. J Bone Miner Res 2012;27:2259-2263.

29 Li X, Ominsky MS, Warmington KS, Morony S, Gong J, Cao J, Gao Y, Shalhoub V, Tipton B, Haldankar R, Chen Q, Winters A, Boone T, Geng Z, Niu QT, Ke HZ, Kostenuik PJ, Simonet WS, Lacey DL, Paszty C: Sclerostin antibody treatment increases bone formation, bone mass, and bone strength in a rat model of postmenopausal osteoporosis. J Bone Miner Res 2009;24:578-588.

-30 Ominsky MS, Vlasseros F, Jolette J, Smith SY, Stouch B, Doellgast G, Gong J, Gao Y, Cao J, Graham K, Tipton B, Cai J, Deshpande R, Zhou L, Hale MD, Lightwood DJ, Henry AJ, Popplewell AG, Moore AR, Robinson MK, Lacey DL, Simonet WS, Paszty C: Two doses of sclerostin antibody in cynomolgus monkeys increases bone formation, bone mineral density, and bone strength. J Bone Miner Res 2010;25:948-959.

-31 Padhi D, Jang G, Stouch B, Fang L, Posvar E: Single-dose, placebo-controlled, randomized study of AMG 785, a sclerostin monoclonal antibody. J Bone Miner Res 2011;26:19-26.

-32 Padhi D, Allison M, Kivitz AJ, Gutierrez MJ, Stouch B, Wang C, Jang G: Multiple doses of sclerostin antibody romosozumab in healthy men and postmenopausal women with low bone mass: A randomized, doubleblind, placebo-controlled study. J Clin Pharmacol 2014;54:168-178.

33 McClung MR, Grauer A, Boonen S, Bolognese MA, Brown JP, Diez-Perez A, Langdahl BL, Reginster JY, Zanchetta JR, Wasserman SM, Katz L, Maddox J, Yang YC, Libanati C, Bone HG: Romosozumab in Postmenopausal Women with Low Bone Mineral Density. N Engl J Med 2014;370:412-420.

-34 McColm J, Hu L, Womack T, Tang CC, Chiang AY: Single- and multiple-dose randomized studies of blosozumab, a monoclonal antibody against sclerostin, in healthy postmenopausal women. J Bone Miner Res 2014;29:935-943. 